\title{
World and European Federalist Movements: Building a Closer Cooperation to Achieve a Common Goal
}

Pilar Llorente

The world needs more than ever a strong international community - but not one built solely upon sovereign states, but an international community understood as a global civil society, whose rights and interests are represented in democratic supranational institutions working towards a better balance in the distribution of resources and power in the planet. Federalism, whether applied at a regional or a global scale, is just about that, building democratic supranational institutions that allow a multi-level governance where not only the states, but the citizens, are the main important political actors.

The world has changed much since the end of WWII and the cold war: it has become multipolar, with delocalized centres of power and a clear shift of economic and political influence from the North-West (Atlantic world) to the global East and South. Besides, there is an increasing need for global policies to address inequality, climate change, financial regulation or terrorism, among others. However, the global institutional architecture seems trapped in the post cold war paradigm and has not sufficiently adapted to these changes: states are still the main actors in the policy making, which results in global challenges being tackled in a fragmented and ineffective way, by decision that lack democratic legitimacy. And again, this is where federalism, built at regional and global level, can help both address the need for effectiveness and democratization of the supranational political action.

The (still under construction) European Federation has already proven successful in building peace and prosperity, fostering regional cohesion, expanding citizens rights and protecting the environment and, despite its flaws and weaknesses, shows that the building of supranational democratic institutions and the sharing of competences among former sovereign states produces a more suitable architecture to deal with global challenges than the Westphalian model. If the market has already become global and the most important societal challenges are also global, why should political power still (and with it citizens representation) be constrained to national borders? This experience of regional federation-building can deliver equally beneficial changes to other regions and should lead in the next steps to the optimal model to achieve a global democratic order: a world federation that guarantees equal rights and opportunities to citizens and extends the rule of law to the global level. If the process of European integration has to a big extent produced a true European demos, a world federation would eventually lead to a global demos, that's to say, the political expression of the unity of mankind and the equality of civil rights.

World and European federalists share the same general objectives (establishment of supranational democratic institutions in the 
legislative, judiciary and executive powers) and fight the same enemies (nationalism, authoritarianism, racism) and, even if the specific challenges and the timeline of their roadmap are different, they can be much more effective in their respective struggles by joining forces and learning from each other's achievements. Let's take as example the evolution of the European Parliament from a consultative assembly, to a democratic elected body with legislative competence and with power to control the executive (European Commission): the same way, an initially consultative parliamentary assembly of United Nations formed by members of national parliaments could evolve to a legislative body with members directly elected from citizens all around the world. Another example is the progressive construction of a federal fiscal system and the capacity of federal governments to levy taxes. A financial transaction tax and a carbon tax - both at European and global levels - would contribute to a more ethical financial system and the mitigation of climate change, while allowing the investment on federal policies and the provision of global public goods. Even if European federalists are closer to their specific goal, we must become aware that a European Federation can never be sustainable in a world governed by international anarchy, inequality and depletion of natural resources. Similarly, the world federalists would benefit from the realization of a true European Federation, which would be the first successful attempt of regional integration that manage to combine market economy, democracy, rule of law and environmental protection and can serve as a trigger for similar processes around the world, producing regional political actors that would be in a better position to integrate in a global federation that the rigid sovereign states are. The process of regional and global federalization are to a big extent interlinked, and so the movements defending one and the other could mutually benefit from a closer collaboration.

We must admit there is some divergence in the definition of the specific objectives and priorities of both organizations: while the UEF focuses almost exclusively in the improving of the EU institutional functioning and the establishment of a true European Federation and does give not as much consideration to global initiatives beyond its borders, the strengthening of the different regional integration processes (of which the EU is the most advanced example) does not seem to appear among the priority initiatives of the WFM. However, divergences and diversity of approaches can be enriching if both movements are able to learn from each other's achievements, try to look at themselves through the eyes of their brother organization, take into account constructive criticism and build a common agenda. There are numerous concrete ways in which UEF and WFM can collaborate, such as definition of policies for global challenges, institutional cooperation or joint activism, among many others.

Regarding the policy making, most of the current societal challenges need to be examined jointly from the regional (in this case, European) and global perspective: political governance (the building of a European government would impact on the options of the much needed reform of the UN), financial regulations, trade, environment, asylum, migration and circulation of people, rights of minorities and protection of diversity, education and research, fiscal and economic policies, to name just a few. Having a federalist agenda that would refer both to regional and global policy options would certainly provide with a coherent and comprehensive political vision that would benefit the support of federalism at all levels. In this way, UEF could adopt 
WFM objectives as part of its agenda of EU external policy and support WFM initiatives by advocating for them at the EU institutions and acting as WFM ambassadors.

A coordinated and coherent joint action requires also the participation of members of each movements in the assemblies and committees of their brother organization. In this way, the participation of WFM members in the UEF Europe Federal Committees and events has always enriched the debate and broadened the perspective, and similarly, the attendance of UEF members to the last WFM council meeting in the Hague in February 2017 was a great opportunity to exchange views, learn from each other and realize once more how satisfying a closer collaboration can be.

Activism and engagement of citizens and organizations of the civil society are in the genes of both World and European federalism: working on joint campaigns and get involved each other endeavours to reach a critical mass of citizens' support, establishing permanent dialogue with NGOs, catalyze citizens demands and concerns and provide federalist solutions, foster intercultural communication and facilitating understanding of federalist ideas are just some activities where are joint effort of World and European federalist can achieve much greater impact. A fantastic example of collaboration of WFM and UEF in engaging citizens in the federalist debate is the international seminar in Ventotene, which yearly brings together people from all over the world to discuss global political, economic and social matters from a both European and World federalist perspectives, thereby transmitting federalist ideals and encouraging intercultural dialogue and inspiring political involvement and action.

The emergence of a global civil society becomes evident not only in the universalization of some cultural and technological trends, but also in the coordinated uprising of individuals against global injustice, as in the demonstrations all over the world against the unfair globalization, against the unethical behavior of Wall Street or against the unprovoked invasion of Iraq, to mention just a few. It is the emergence of a global society that has become aware of its rights and claims for them, it is the time for citizens to participate in the global political action through their representation in democratic federations. 